ISSN 1392-3196 / e-ISSN 2335-8947

Zemdirbyste-Agriculture, vol. 101, No. 4 (2014), p. 347-354

DOI 10.13080/z-a.2014.101.044

\title{
Effect of tillage, lime sludge and cover crop on soil physical state and growth of spring oilseed rape
}

\author{
Aleksandras VELYKIS, Antanas SATKUS, Laura MASILIONYTE \\ Joniškèlis Experimental Station, Lithuanian Research Centre for Agriculture and Forestry \\ Joniškèlis, Pasvalys distr., Lithuania \\ E-mail: velykisalex@gmail.com
}

\begin{abstract}
Research was carried out during 2008-2010 at the Joniškèlis Experimental Station of the Lithuanian Research Centre for Agriculture and Forestry on a clay loam Endocalcary-Endohypogleyic Cambisol (CMg- $n$-w-can). The aim of the present study was to determine effects of deep $(20-23 \mathrm{~cm})$ and shallow $(15-17 \mathrm{~cm})$ ploughing, ploughless tillage $(10-12 \mathrm{~cm})$, combinations of ploughless tillage $(10-12 \mathrm{~cm})$ with incorporation of lime sludge and cover crop (mixture of field pea, common vetch and blue lupine) for green manure and application of the same cover crop for mulch without autumn tillage on soil physical properties and growth of spring oilseed rape (Brasica napus L.) crop. After shallow ploughing the soil water content in seedbed $(0-5 \mathrm{~cm})$ for spring oilseed rape right after its sowing was significantly lower in droughty years (with duration of post-sowing period without rainfall for 18 and 20 days in 2008 and 2009, respectively) and crop emergence was worse compared to deep ploughing. Due to ploughless tillage, the soil water content in seedbed was significantly lower in droughty years and seedbed structure was worse in sufficiently wet year compared to deep ploughing. Incorporation of lime sludge by ploughless tillage resulted in significantly higher soil water content at $5-15 \mathrm{~cm}$ depth, better seedbed structure and greater crop germination rate compared to ploughless tillage alone. Incorporation of lime sludge also increased oilseed rape yield by $11.1 \%$ in droughty year. Having incorporated the cover crop for green manure late in autumn by ploughless tillage the oilseed rape in droughty years germinated significantly worse, the soil water content remaining in the seedbed after emergence was lower and the yield decreased by $19.8 \%$ compared to ploughless tillage. Having left the cover crop mulch over winter without autumn tillage demonstrated significantly higher soil water content at 5-15 cm depth after oilseed rape sowing; however, in droughty years the seedbed became drier, its structure deteriorated, the crop germinated worse and yield decreased by $12.1-17.3 \%$ compared to ploughless tillage. Spring oilseed rape germination rate in droughty years was influenced by the soil water content in the seedbed after sowing $(r=0.56, P<0.01)$, content of $2-5 \mathrm{~mm}$ soil aggregate fraction in seedbed $(r=0.50, P<0.05)$ and by the seedbed structure, expressed as an index $(r=0.50, P<0.05)$, while crop yield - by the seedbed structure $(r=0.67, P<0.01)$ and by the germination rate $(r=0.74, P<0.01)$.
\end{abstract}

Key words: Brassica napus, crop emergence, green manure, mulch, ploughless tillage, soil water content, yield.

\section{Introduction}

Choosing appropriate soil tillage is one of the most important conditions determining the profitability of crop production. The majority of plant growth factors affecting the yield and its quality are governed by tillage. Conventional deep ploughing of heavy soils requires a great deal of energy and time input as well as financial resources. The necessity of retaining soil organic matter, the supply of new machinery, the changes in farm specialization, new environmental requirements and other reasons have prompted a search for ways to simplify tillage (Morris et al., 2010; Soane et al., 2012).

The feasibility of applying reduced tillage depends on soil texture, physical and chemical properties, climatic conditions, species of cultivated crops and other factors. Timing according to soil physical condition is more important for reduced tillage compared to the conventional one, as in the case of ploughless tillage, soil compaction and damage caused by vehicles are possible closer to the soil surface. Reduced tillage in Lithuania and Northern European countries is used more often for winter crops as due to rainy weather in autumn the quality of seedbed is not so important for seed germination (Anken et al., 2004; Tausojamoji žemdirbystė..., 2008; Riley et al., 2009).

A soil type can have significant influence on successful application of reduced tillage. Reduced tillage is relatively well suited for the soils of structured clay as they reduce the risk of the formation of a highly cloddy and dry seedbed; conversely, light but unstructured sandy loam soils are less suitable for ploughless tillage as reduced tillage results in poor structure and disturbance of air and water movement along the soil profile. Reduced tillage is often less efficient compared to conventional ploughing in the soils with low amount of organic carbon and poor physical properties. Drier and stable structured soils are better suited for reduced tillage (Morris et al., 2010; Soane et al., 2012). 
The application of direct sowing technologies without prior tillage in the northern regions of Europe allows earlier sowing of winter crops; however, there the soils warm up and dry up more slowly in spring, therefore, the sowing and germination of spring crops can be delayed. The soils unploughed during the primary autumn tillage in spring are more compacted compared to the ploughed ones and it is more complicated to perform crop sowing during very wet and very dry seasons. Plant root penetration and water absorption in untilled soils are highly affected by the vertical pores made by earthworms. Untilled soils are less damaged by the traffic of heavy machinery during harvesting due to better trafficability; however, plant residues should be well chopped and distributed evenly prior to direct sowing. Under droughty conditions the plant residues left on the soil surface prevent new crop germination as they worsen the contact between seeds and soil (Van den Putte et al., 2010; Soane et al., 2012).

Seedbed preparation is important for crop germination, growth and yield. The soil physical environment is the basis of conditions under which crop germination, growth and development take place. A range of soil factors influence crops since the very sowing: temperature, water content, availability of oxygen, bulk density, etc. The influence of these factors is determined by the parameters of the prepared seedbed (Håkansson et al., 2002; Atkinson et al., 2007; Håkansson et al., 2011).

Spring oilseed rape is suitable for cultivation in all crop rotations due to retaining soil fertility and its structural improvement. The success of oilseed rape cultivation highly depends on good germination. The application of reduced tillage for spring oilseed rape can cause different problems in the appropriate drilling, achievement of good germination and growth. The obstacle to that may be cloddy soil and the plant residues left on its surface. Oilseed rape is sensitive to soil compaction. However, it has been observed that oilseed rape roots can penetrate better through solid layers of soil using pores and cracks compared to wheat roots (Sauzet et al., 2003; Peltonen-Sainio et al., 2011).

The investigations carried out in the Lithuanian research institutions proved that it is feasible to apply reduced tillage in different zones of the country. However, the application of reduced ploughless tillage, especially no-till, causes different problems: higher incidence of perennial weeds, differentiation of the soil plough layer into an upper layer richer in nutrients and organic materials and a less rich lower layer, deterioration of the physical properties of the lower layer, shortage of nitrogen, etc. (Romaneckas et al., 2009; Feiza et al., 2011). The application of reduced primary tillage for spring crops in clayey soils often results in poorer yields due to the deterioration of physical and other properties of the mentioned soils (Tausojamoji žemdirbyste..., 2008). Because of the diversity of soils and climatic conditions, efficient systems of reduced tillage should be developed for the crops cultivated in different regions. The systems of reduced tillage for cultivating spring oilseed rape in Lithuanian clay loams have still not been investigated sufficiently. The research carried out was not focused on additional means ensuring good germination and development of spring oilseed rape while applying reduced tillage under different weather conditions.

The objective of the current study was to evaluate the influence of deep and shallow ploughing, and reduced tillage and its combinations with the incorporation of lime sludge and the use of cover crops as green manure and mulch on soil physical properties, germination and growth of spring oilseed rape (Brasica napus L.) crop.

Work hypothesis: soil tillage can be reduced for spring oilseed rape in clay loams, if appropriately chosen methods of reduced tillage ensure fast oilseed rape germination and the required density of crop under the droughty conditions during the post-sowing period.

\section{Materials and methods}

Site and soil. The study was carried out at the Joniškèlis Experimental Station of the Lithuanian Research Centre for Agriculture and Forestry situated in the Northern part of Central Lithuania's lowland $\left(56^{\circ} 21^{\prime}\right.$ $\mathrm{N}, 24^{\circ} 10^{\prime}$ E) during the period 2008-2010. The soil of the experimental site is Endocalcari-Endohypogleyic Cambisol (CMg-n-w-can). Topsoil $(0-25 \mathrm{~cm})$ texture clay loam ( $27 \%$ clay, $50 \%$ silt, $23 \%$ sand), humus content $-2.2 \%$ and $\mathrm{pH}-6.6$. The annual mean temperature and total amount of precipitation are $6.1^{\circ} \mathrm{C}$ and $547.4 \mathrm{~mm}$.

Experimental design. The experiment examined the effects of conventional and reduced tillage as well as the combinations of reduced tillage with practices for soil improvement on soil physical properties and spring oilseed rape emergence, growth and yield. The following tillage systems were investigated: 1$)$ deep $(20-23 \mathrm{~cm})$ ploughing (DP), 2) shallow (15-17 cm) ploughing (SP), 3) ploughless tillage at $10-12 \mathrm{~cm}$ depth (PT), 4) ploughless tillage at $10-12 \mathrm{~cm}$ depth with lime sludge incorporation $(\mathrm{PT}+\mathrm{LS}), 5)$ ploughless tillage at 10-12 cm depth with cover crop incorporation for green manure (PT + GM), 6) no tillage in autumn with cover crop for winter mulch $(\mathrm{NT}+\mathrm{WM})$. Crop rotation $(1$ - field pea, 2 - winter wheat, 3 - spring oilseed rape, 4 - spring barley) was spread over space and time. The field trial was arranged in a randomized single row design with four replicates. Each sub-plot size was $80 \mathrm{~m}^{2}(16.0 \times 5.0 \mathrm{~m})$ of which $29.9 \mathrm{~m}^{2}(13.0 \times 2.3 \mathrm{~m})$ was harvested.

Agronomic practices. The pre-crop (winter wheat) straw was chopped during harvesting and incorporated into the soil at $6-8 \mathrm{~cm}$ depth during stubble cultivation. Cover crop was the mixture of field pea (Pisum sativum L. (Partim) cv. IP-5 (90 kg ha ${ }^{-1}$ seed), common vetch (Vicia sativa L.) cv. 'Baičiai' (50 kg ha ${ }^{-1}$ seed) and blue lupine (Lupinus angustifolius L.) cv. 'Boruta' (60 kg ha-1 seed). Post-harvest cover crop was sown after stubble cultivation. Deep (treatment 1) and shallow (treatment 2) ploughing was carried out with a mouldboard plough, ploughless tillage (treatments 3 and 4) by a combined stubble cultivator. Lime sludge $\left(7.0 \mathrm{tha}^{-1}\right)$ was incorporated into the soil during ploughless tillage operation (treatment 4). Cover crop for green manure (treatment 5) was incorporated into the soil by a disk harrow late in autumn. Cover crop for winter mulch (treatment 6) was left without any tillage in autumn and its frost killed residues covered the soil. Spring oilseed rape (Brasica napus L.) cv. 'Senator' was grown. It was sown at a rate of $7 \mathrm{kgha}^{-1}$ by a drill with wedgetype coulters after pre-sowing tillage by a cultivator. Crop fertilization $-\mathrm{N}_{120} \mathrm{P}_{90} \mathrm{~K}_{60}$. The herbicide Galera 334 (a.i. clopyralid $267 \mathrm{~g} \mathrm{l}^{-1}$ and picloram $67 \mathrm{gl}^{-1}$ ) $0.351 \mathrm{ha}^{-1}$ with selective mode of action was applied.

Weather conditions. The period after harvesting in 2007 was not substantially different from the long- 
term mean in terms of air temperature and precipitation amount. The year 2008 was distinguished by a warmer winter, wet spring and very dry first half and the end of summer (Fig. 1). The droughts determined the poor germination of spring oilseed rape. The period from November 2008 to April 2009 was warm and humid. A lot of precipitation fell in December and March (63.1 and $51.7 \mathrm{~mm}$, respectively). Very droughty weather in April and May 2009 resulted in poor germination of spring

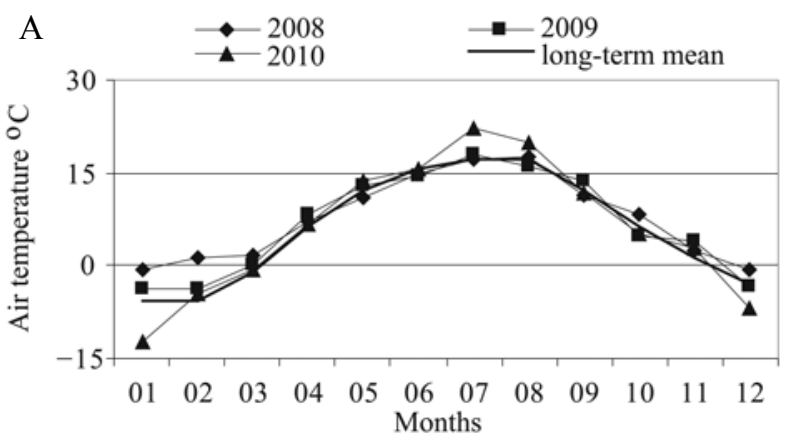

oilseed rape. Later, in June and July it was very wet. The period after harvesting was humid and warm, which was favourable for cover crops; however, drought occurred again in September. April 2010 was drier than the longterm mean. Abundant precipitation in May improved the germination of spring oilseed rape. The summer of 2010 was especially hot and wet. Droughty post-sowing period (without rainfall) continued for 18 days in 2008, 20 days in 2009, and 10 days in 2010 .

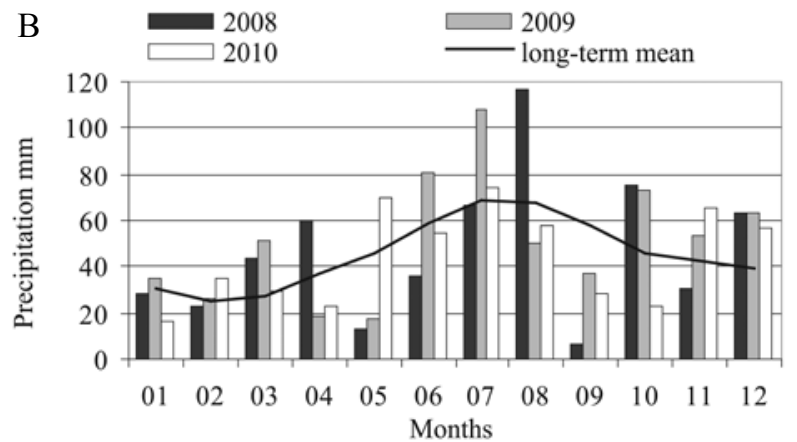

Figure 1. Mean air temperature (A) and amount of precipitation (B) during the study and long-term periods (data from Joniškėlis Experimental Station's meteorological site)

Analytical methods, assessments and statistical procedures. The following assessments were made: 1) soil water content (weighing method) directly after sowing of spring oilseed rape and after full crop emergence at $0-5$ and $5-15 \mathrm{~cm}$ depths; 2) fractions of soil aggregates in seedbed $(0-5 \mathrm{~cm})$ structure directly after sowing according to the method, described by Håkansson et al. (2002). Seedbed structure index $\left(\mathrm{C}_{\mathrm{st}}\right)$ for estimation of integrated importance of all fractions on seedbed structure was calculated in the following way: $C_{\text {st }}=A_{2} /\left(A_{1}+A_{3}\right)$, where $\mathrm{A}_{1}$ - amount of soil aggregates $<2 \mathrm{~mm}, \%(\mathrm{v} / \mathrm{v}), \mathrm{A}_{2}$ - amount of soil aggregates $2-5 \mathrm{~mm}, \%(\mathrm{v} / \mathrm{v}), \mathrm{A}_{3}$ - amount of soil aggregates $>5 \mathrm{~mm}, \%$ (v/v) (Теории и методы..., 2007). Oilseed rape seedlings were counted every three days after the beginning of emergence until full emergence; rape plants were also counted before harvesting. Measurements were done in four sites (plot $0.25 \mathrm{~m}^{2}$ ). Index of germination intensity $\left(\mathrm{C}_{\mathrm{ge}}\right)$ for estimation of seed germination rate was calculated in the following way: $\mathrm{C}_{\mathrm{ge}}=\left(\mathrm{D}_{\mathrm{S} 1} / \mathrm{l}_{1}+\mathrm{D}_{\mathrm{S} 2} / \mathrm{l}_{2}+\ldots\right.$ $\left.+\mathrm{D}_{\mathrm{Sn}} / \mathrm{ln}\right) / \mathrm{N}$, where $\mathrm{D}_{\mathrm{S} 1}, \mathrm{D}_{\mathrm{S} 2}, \ldots \mathrm{D}_{\mathrm{Sn}}$ is number of seedlings, $1_{1}, 1_{2}, \ldots, \ln$ - period of days from the date of oilseed rape sowing till the final counting of seedlings, $\mathrm{N}$ - number of seedling counts (Tausojamoji žemdirbyste..., 2008). The seed yield of spring oilseed rape was adjusted to $9.0 \%$ (w/w) standard moisture. The results were processed by analysis of variance and correlation-regression analysis using the softwares ANOVA and STAT-ENG. The symbols * and ** denote statistically significant at 0.05 and 0.01 probability level.

\section{Results and discussion}

Soil water content. A seedbed prepared for spring crops in clay loam soils in spring become over-dried very fast. When droughty post-sowing periods continue for a longer time, the germination of spring crop seeds can quite often be poor. Swedish researchers propose that in order to achieve good germination of seeds the water content in soil beneath seeds must exceed the moisture of plant wilting by at least 5\% (Håkansson et al., 2011). The soil water content in the $0-5 \mathrm{~cm}$ depth seedbed layer right after the sowing of spring oilseed rape exceeded plant wilting point water content, which accounted for $100 \mathrm{~g} \mathrm{~kg}^{-1}$ or $10.0 \%(\mathrm{w} / \mathrm{w})$ in clay loam soils (Tausojamoji žemdirbystè..., 2008), only once (2008) in three years of our research and it reached $102.8-124.9 \mathrm{~g} \mathrm{~kg}^{-1}$. In 2009 and 2010, the seedbed layer was drier and it did not reach plant wilting point water content except the PT + LS and NT + WM in 2010 (Table 1). The assessment of soil water content in the $0-5$ and $5-15 \mathrm{~cm}$ layers right after spring oilseed rape sowing did not yield any significant relationship between different conditions of individual research years and methods of tillage applied. According to the average data of 2008-2010, no significant differences of soil water content in the seedbed $(0-5 \mathrm{~cm})$ were established while applying different autumn tillage methods. The soil water content beneath a seedbed (5$15 \mathrm{~cm}$ depth) is an important moisture reserve for good emergence of crops. Deep and shallow ploughing as well

Table 1. Soil water content $\left(\mathrm{g} \mathrm{kg}^{-1}\right)$ directly after spring oilseed rape sowing

\begin{tabular}{ccccccc}
\hline Tillage and its & Depth & \multicolumn{4}{c}{ Year } \\
\cline { 3 - 6 } combinations & $\mathrm{cm}$ & 2008 & 2009 & 2010 & \\
\hline \multirow{2}{*}{ Deep ploughing (DP) } & $0-5$ & 102.8 & 81.5 & 82.4 & 88.9 \\
& $5-15$ & 177.4 & 166.5 & 158.2 & 167.4 \\
Shallow ploughing (SP) & $0-5$ & 116.5 & 72.1 & 92.1 & 93.6 \\
& $5-15$ & 178.2 & 166.2 & 170.0 & 171.5 \\
& $0-5$ & 124.9 & 90.1 & 97.3 & 104.1 \\
Ploughless tillage (PT) & $5-15$ & 174.4 & 171.4 & 166.0 & 170.6 \\
Ploughless tillage with & $0-5$ & 108.6 & 84.1 & 115.5 & 102.7 \\
lime sludge (PT + LS) & $5-15$ & 181.4 & 176.1 & 173.7 & $177.1 *$ \\
Ploughless tillage with & $0-5$ & 119.8 & 74.5 & 91.7 & 95.3 \\
green manure (PT + GM) & $5-15$ & 177.1 & 173.1 & 172.7 & 174.3 \\
No tillage in autumn with & $0-5$ & 112.2 & 73.0 & 109.5 & 98.2 \\
winter mulch (NT + WM) & $5-15$ & 183.8 & 180.4 & 177.5 & $180.6 *$ \\
\hline & & $0-5$ & 32.41 & 16.19 & 20.71 & 16.65 \\
\hline \multirow{2}{*}{ LSD $_{05}$} & $5-15$ & 22.39 & 10.19 & 10.97 & 5.76 \\
\hline
\end{tabular}

Interaction of treatment and year $F$-act.: $0-5 \mathrm{~cm}-1.32,5-15 \mathrm{~cm}$ $-0.44$ 
as PT resulted in no significant variation of soil water content in this depth. Due to NT + WM and PT + LS, the soil water content in this layer was significantly higher by 10.0 and $6.5 \mathrm{~g} \mathrm{~kg}^{-1}$, respectively compared to PT.

The conditions of certain years determined the influence of the investigated tillage on the soil water content only in the seedbed layer $(0-5 \mathrm{~cm})$ after spring oilseed rape emergence (Table 2). In droughty 2008 and 2009, when after spring oilseed rape sowing there was no rainfall for 18 and 20 days, respectively, the seedbed layer $(0-5 \mathrm{~cm})$ after crop emergence was very dry and the soil water content was only 44.3-57.6 and $55.0-82.3 \mathrm{~g} \mathrm{~kg}^{-1}$, respectively. In 2010 , when there was no rainfall only for 10 days after sowing, the soil water content in the seedbed after oilseed rape emergence was $170.0-182.6 \mathrm{~g} \mathrm{~kg}^{-1}$ and it was favourable for crop growth. In 2008, a significantly drier seedbed was achieved due to SP and PT, and in 2009 - due to SP compared with DP. Having applied PT + LS the seedbed in 2008 had significantly higher (12.1 $\left.\mathrm{g} \mathrm{kg}^{-1}\right)$ water content; however, in 2009 the seedbed dried even more (by 27.0 and $18.0 \mathrm{~g} \mathrm{~kg}^{-1}$ ) after NT + WM and PT + GM had been applied compared to PT alone. In 2010, the lowest soil water content in the oilseed rape seedbed was observed after SP. Investigated measures had no significant effect on soil water content at a depth of 5-15 cm after oilseed rape emergence (data not shown).

Table 2. Soil water content $\left(\mathrm{g} \mathrm{kg}^{-1}\right)$ in the seedbed layer $(0-5 \mathrm{~cm})$ after spring oilseed rape emergence

\begin{tabular}{|c|c|c|c|}
\hline \multirow{2}{*}{$\begin{array}{l}\text { Tillage and its } \\
\text { combinations }\end{array}$} & \multicolumn{3}{|c|}{ Year } \\
\hline & 2008 & 2009 & 2010 \\
\hline Deep ploughing (DP) & 57.6 & 75.1 & 177.9 \\
\hline Shallow ploughing (SP) & $44.8^{*}$ & $64.0^{*}$ & $170.0^{*}$ \\
\hline Ploughless tillage (PT) & $44.3^{*}$ & 82.0 & 182.6 \\
\hline $\begin{array}{l}\text { Ploughless tillage with lime sludge } \\
(\text { PT + LS) }\end{array}$ & $56.4^{*}$ & 82.3 & 182.3 \\
\hline $\begin{array}{l}\text { Ploughless tillage with green manure } \\
(\mathrm{PT}+\mathrm{GM})\end{array}$ & 52.3 & $64.0^{*}$ & 181.8 \\
\hline $\begin{array}{l}\text { No tillage in autumn with winter mulch } \\
\text { (NT + WM) }\end{array}$ & 49.1 & $55.0^{*}$ & 178.2 \\
\hline $\mathrm{LSD}_{05}$ & 11.92 & 10.21 & 7.27 \\
\hline
\end{tabular}

Interaction of treatment and year $F$-act. $-3.10^{* *}$

The changes in soil water content as influenced by different tillage technologies depend on the soil type and conditions during tillage, equipment used, tillage depth, weather conditions and many other factors. The research carried out on the loamy soils in Central Lithuania indicates that for spring oilseed rape germination in dry conditions direct drilling and reduced tillage are superior to conventional ploughing as right after sowing the crops are able to use a higher amount of productive moisture (Šimanskaitè et al., 2009). Jodaugiene et al. (2004) suggest that the application of reduced tillage (shallow ploughing, deep and shallow ploughless tillage) in cultivating spring oilseed rape had no negative influence on the changes of topsoil water content in loam soils. In clayey soils of Northern Lithuania with predominant silty fraction capillary water rises up fast which can cause the overdrying of both upper and deeper layers of soil (Tausojamoji žemdirbystè..., 2008). The investigations of different conservation and conventional tillage strategies carried out as long-term field experiments in Germany established that higher water content can be accumulated in the 0-30 cm layer of the better loosened soil in autumn, which determines better conditions of emergence for the crops drilled in spring (Gruber et al., 2011). Cover crops protect soil against the detrimental impact of raindrops. The mulch layer of cover crops retains the evaporation of soil water (Cherr et al., 2006; Morris et al., 2010).

Seedbed structure. Spring oilseed rape requires a fine, densified and uniform seedbed allowing sowing in the $1.5-2.5 \mathrm{~cm}$ depth. Tillage at such precise depth is very complicated. When soil is tilled deeper than required for seed incorporation, the seeds are not watered by the moisture rising up by capillaries from deeper layers of unloosened soil. Therefore, in order to achieve good emergence of spring oilseed rape a very important condition is an appropriate structure of the seedbed prepared, which has to ensure good contact between seeds and soil. Soil aggregate size distribution is the main attribute of seedbed quality. The primary tillage system applied determines seedbed quality; however, the formation of the optimum aggregate size in a seedbed depends on a range of factors including a soil type and its water content during pre-sowing tillage (Morris et al., 2010). According to Swedish scientists (Håkansson et al., 2002), the greatest agronomic value in a seedbed lays within 2-5 mm size soil aggregates.

In our research, the conditions of certain years determined the influence of tillage only on the changes in the $2-5 \mathrm{~mm}$ size soil aggregate fraction in the seedbed (Table 3). Due to the NT + WM the amount of 2-5 mm size soil aggregates in the seedbed in 2008 and 2009

Table 3. Amount of soil aggregates and structure index in spring oilseed rape seedbed layer $(0-5 \mathrm{~cm})$

\begin{tabular}{|c|c|c|c|c|c|c|}
\hline \multirow{2}{*}{$\begin{array}{l}\text { Tillage and its } \\
\text { combinations }\end{array}$} & \multicolumn{3}{|c|}{ Soil aggregates of $2-5 \mathrm{~mm}$ size $\%(\mathrm{v} / \mathrm{v})$} & \multicolumn{3}{|c|}{ Structure index } \\
\hline & 2008 & 2009 & 2010 & 2008 & 2009 & 2010 \\
\hline Deep ploughing (DP) & 24.1 & 28.2 & 35.7 & 0.32 & 0.40 & 0.55 \\
\hline Shallow ploughing (SP) & 25.8 & 30.4 & 35.6 & 0.35 & 0.44 & 0.57 \\
\hline Ploughless tillage (PT) & 26.0 & 25.2 & $29.0 *$ & 0.35 & 0.34 & $0.41^{*}$ \\
\hline $\begin{array}{l}\text { Ploughless tillage with } \\
\text { lime sludge (PT + LS) }\end{array}$ & 28.3 & 24.9 & 32.0 & 0.40 & 0.33 & 0.47 \\
\hline $\begin{array}{l}\text { Ploughless tillage with } \\
\text { green manure }(\mathrm{PT}+\mathrm{GM})\end{array}$ & 27.3 & 23.3 & 28.3 & 0.38 & 0.31 & 0.39 \\
\hline $\begin{array}{l}\text { No tillage in autumn with } \\
\text { winter mulch (NT + WM) }\end{array}$ & $21.1^{*}$ & $18.8^{*}$ & 28.6 & $0.27 *$ & $0.23 *$ & 0.40 \\
\hline $\mathrm{LSD}_{05}$ & 3.54 & 4.80 & 4.40 & 0.067 & 0.087 & 0.100 \\
\hline
\end{tabular}

Interaction of treatment and year $F$-act.: soil aggregates $2-5 \mathrm{~mm}-2.69 * *$, structure index $-3.13 * *$ 
was significantly lower compared to PT. In 2010, it was established that due to PT the amount of 2-5 mm size soil aggregates in the seedbed was significantly lower compared to DP. According to the average data of 2008 2010 , the proportion of cloddy $(>5 \mathrm{~mm})$ soil aggregate fraction in the seedbed structure decreased significantly after PT + LS had been applied and it increased after the application of NT + WM compared to PT (Table 4). The importance of all soil aggregate fractions is better illustrated by the structure index as an indicator of integrated seedbed quality. According to this indicator, the seedbed prepared for spring oilseed rape in 2008 and 2009 was significantly worse due to the NT + WM compared to PT, and in 2010 it was significantly worse due to PT compared to DP (Table 3 ).

The soil water content during tillage has a substantial impact on soil properties and labour costs. In Sweden it was established that after the autumn tillage of the clay soil with low water content $(0.76 \times$ plastic limits $)$ finer aggregates prevailed in the seedbed prepared in spring and the soil conditions for crop growth were more favourable (Arvidsson, Bölenius, 2006). Late tillage of clayey soil in autumn under wet soil conditions $(1.01 \times$ plastic limits) resulted in the deterioration of the seedbed prepared in spring and a lower germination rate. In our research while incorporating cover crop biomass as green manure during ploughless tillage later in the autumn the soil was moister compared with other tillage methods. In addition, in spring before pre-sowing tillage, due to the reduction of autumn tillage intensity and especially due to winter mulch without autumn tillage and ploughless tillage together with green manure incorporation the soil of the upper topsoil layer was substantially less dry. These conditions could determine the seedbed deterioration.

Table 4. Amount of $>5 \mathrm{~mm}$ soil aggregates in spring oilseed rape seedbed layer $(0-5 \mathrm{~cm})$

\begin{tabular}{|c|c|c|c|c|}
\hline \multirow{3}{*}{$\begin{array}{l}\text { Tillage and its } \\
\text { combinations }\end{array}$} & \multicolumn{3}{|c|}{ Year } & \multirow{2}{*}{ Average } \\
\hline & 2008 & 2009 & 2010 & \\
\hline & \multicolumn{4}{|c|}{ Soil aggregates $\%(v / v)$} \\
\hline Deep ploughing (DP) & 40.7 & 54.1 & 43.3 & 46.0 \\
\hline Shallow ploughing (SP) & 41.0 & 47.8 & 42.0 & 43.6 \\
\hline Ploughless tillage (PT) & 39.8 & 58.5 & 54.8 & 51.0 \\
\hline $\begin{array}{l}\text { Ploughless tillage with } \\
\text { lime sludge }(\mathrm{PT}+\mathrm{LS})\end{array}$ & 29.4 & 54.3 & 43.7 & $42.5^{*}$ \\
\hline $\begin{array}{l}\text { Ploughless tillage with } \\
\text { green manure }(\mathrm{PT}+\mathrm{GM})\end{array}$ & 40.6 & 60.8 & 51.1 & 50.9 \\
\hline $\begin{array}{l}\text { No tillage in autumn with } \\
\text { winter mulch (NT + WM) }\end{array}$ & 59.5 & 71.9 & 53.8 & $61.7^{*}$ \\
\hline $\mathrm{LSD}_{05}$ & 10.96 & 10.61 & 9.21 & 5.63 \\
\hline
\end{tabular}

Interaction of treatment and year $F$-act. -1.91

Emergence and growth of spring oilseed rape. The influence of tillage on the emergence of spring oilseed rape depended on the conditions of individual years. During the droughty post-sowing period of 2008 the most intensive emergence of spring oilseed rape was observed having applied PT + LS and the poorest emergence was recorded after SP (Fig. 2, Table 5). Within the prolonged droughty post-sowing period in 2009 the influence of tillage methods on the emergence of oilseed rape was even greater. Under such conditions the most intensive emergence of oilseed rape was observed after PT + LS had been applied, and slower and poorer emergence of oilseed rape was recorded after PT + GM and after NT + WM had been used. Since the year 2010 was more favourable for crop emergence, the influence of tillage methods was less marked; however, a positive effect of $\mathrm{PT}+\mathrm{LS}$ remained.
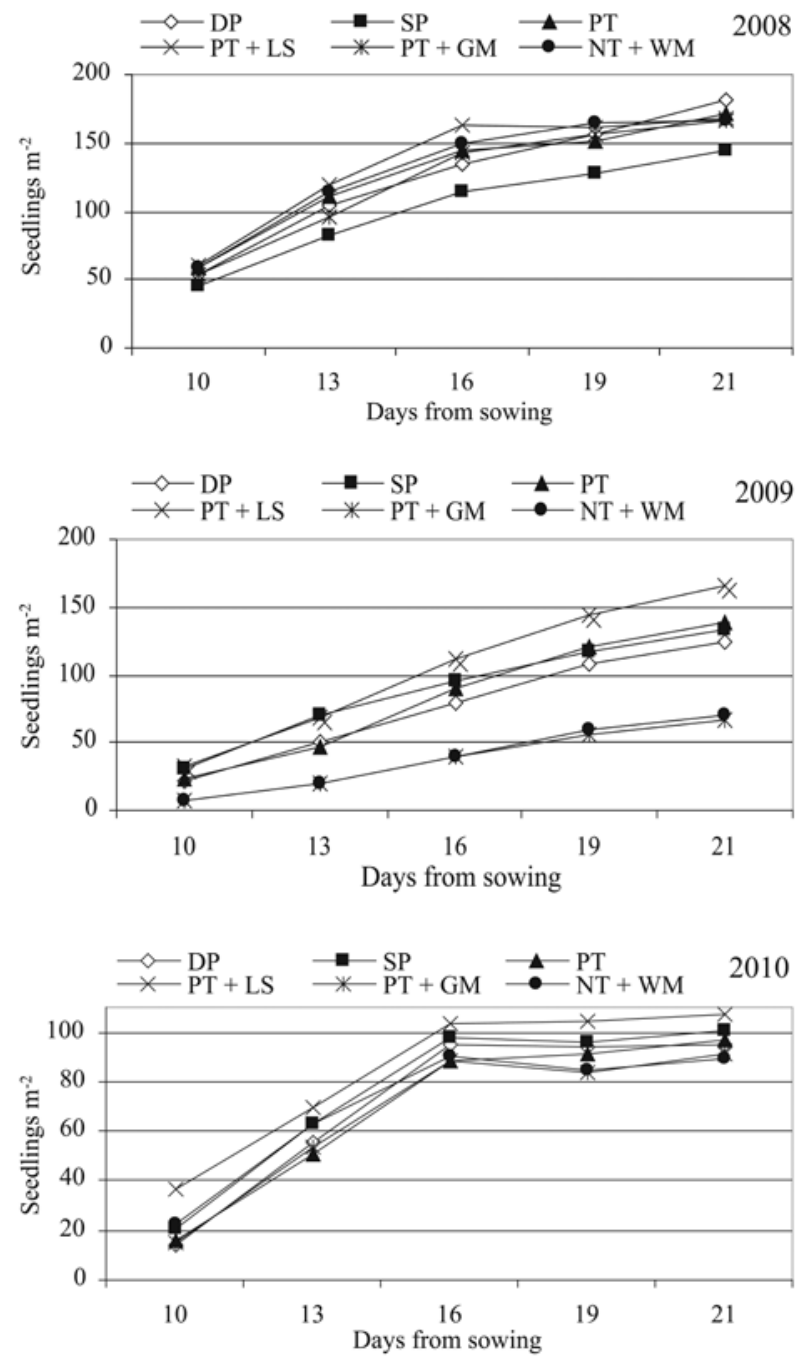

$\mathrm{DP}$ - deep ploughing, SP - shallow ploughing, PT - ploughless tillage, PT + LS - ploughless tillage with lime sludge, PT + GM - ploughless tillage with green manure, NT $+\mathrm{WM}-$ no tillage in autumn with winter mulch

Figure 2. Changes in spring oilseed rape crop density during emergence period

Regardless of the different conditions for spring oilseed rape emergence, the influence of certain years on the crop density before harvesting was not observed. According to the average data of 2008-2010, the densest crop of oilseed rape was achieved after PT + LS had been applied (Table 6). However, no significant crop density differences between the investigated tillage methods were recorded.

In 2009, the year with the longest protracted dry post-sowing period a medium strong direct linear correlation was established between spring oilseed rape germination rate (index of germination intensity) and soil water content in seedbed layer $(0-5 \mathrm{~cm})$ directly after 
Table 5. Germination rate of spring oilseed rape

\begin{tabular}{|c|c|c|c|}
\hline \multirow{3}{*}{$\begin{array}{l}\text { Tillage and its } \\
\text { combinations }\end{array}$} & \multicolumn{3}{|c|}{ Year } \\
\hline & 2008 & 2009 & 2010 \\
\hline & \multicolumn{3}{|c|}{ Index of germination intensity } \\
\hline Deep ploughing (DP) & 6.39 & 3.36 & 4.16 \\
\hline Shallow ploughing (SP) & $5.35^{*}$ & 4.03 & 4.54 \\
\hline Ploughless tillage (PT) & 6.70 & 3.64 & 4.03 \\
\hline $\begin{array}{l}\text { Ploughless tillage with } \\
\text { lime sludge (PT + LS) }\end{array}$ & 7.27 & 4.61 & 5.19 \\
\hline $\begin{array}{l}\text { Ploughless tillage with } \\
\text { green manure (PT + GM) }\end{array}$ & 6.34 & $1.60^{*}$ & 3.95 \\
\hline $\begin{array}{l}\text { No tillage in autumn with } \\
\text { winter mulch (NT + WM) }\end{array}$ & 6.94 & $1.65^{*}$ & 4.26 \\
\hline $\mathrm{LSD}_{05}$ & 0.580 & 1.411 & 1.248 \\
\hline
\end{tabular}

Interaction of treatment and year $F$-act. $-2.42 *$

Table 6. Spring oilseed rape crop density before harvesting

\begin{tabular}{|c|c|c|c|c|}
\hline \multirow{3}{*}{$\begin{array}{l}\text { Tillage and its } \\
\text { combinations }\end{array}$} & \multicolumn{3}{|c|}{ Year } & \multirow{2}{*}{ Average } \\
\hline & 2008 & 2009 & 2010 & \\
\hline & \multicolumn{4}{|c|}{ Number of plants $\mathrm{m}^{-2}$} \\
\hline Deep ploughing (DP) & 95.5 & 89.0 & 82.8 & 89.1 \\
\hline Shallow ploughing (SP) & 90.5 & 91.0 & 93.3 & 91.6 \\
\hline Ploughless tillage (PT) & 106.0 & 101.8 & 89.0 & 98.9 \\
\hline $\begin{array}{l}\text { Ploughless tillage with } \\
\text { lime sludge }(\mathrm{PT}+\mathrm{LS})\end{array}$ & 112.0 & 114.5 & 79.8 & 102.1 \\
\hline $\begin{array}{l}\text { Ploughless tillage with } \\
\text { green manure }(\mathrm{PT}+\mathrm{GM})\end{array}$ & 97.5 & 81.5 & 76.5 & 85.2 \\
\hline $\begin{array}{l}\text { No tillage in autumn with } \\
\text { winter mulch }(\mathrm{NT}+\mathrm{WM})\end{array}$ & 109.5 & 83.8 & 83.8 & 92.4 \\
\hline $\mathrm{LSD}_{05}$ & 18.34 & 20.94 & 16.53 & 18.69 \\
\hline
\end{tabular}

Interaction of treatment and year $F$-act. -1.77

crop sowing $(r=0.56, \mathrm{y}=6.48+0.48 \mathrm{x}, P<0.01)$, as well as between oilseed rape germination rate and content of $2-5 \mathrm{~mm}$ soil aggregate fraction in seedbed structure $(r=$ $0.50, \mathrm{y}=20.46+1.57 \mathrm{x}, P<0.05)$, also between oilseed rape germination rate and seedbed structure index $(r=$ $0.50, \mathrm{y}=0.26+0.03 \mathrm{x}, P<0.05)$. In 2000, the oilseed rape crop density in the middle of germination period ( $3^{\text {rd }}$ measurement) correlated with soil water content at $5-15 \mathrm{~cm}$ depth directly after crop sowing $(r=0.50, \mathrm{y}=$ $18.19+0.14 \mathrm{x}, P<0.05)$.

Different investigations performed in the United Kingdom demonstrate that oilseed rape required up to $33 \%$ of aggregates finer than $5 \mathrm{~mm}$ in diameter in the seedbed in order to ensure good contact between seeds and soil. The presence of huge amounts of large aggregates within a seedbed results in worsened crop emergence due to poor seed-soil contact and uneven sowing depth (Morris et al., 2010). Håkansson et al. (2011) propose that in order to achieve good seed emergence under droughty conditions it is necessary to secure over $50 \%$ of aggregates finer than $5 \mathrm{~mm}$ in the seedbed. It is maintained that when direct drilling and reduced tillage systems are applied in the Northern Europe, slower emergence of spring crops is determined by lower soil temperature (Soane et al., 2012).

Yield of spring oilseed rape. Year conditions determined the influence of the investigated tillage methods on the yield of spring oilseed rape (Table 7). In 2008, the year less favourable for crop emergence and growth (yield 1.39-1.82 $\mathrm{t} \mathrm{ha}^{-1}$ ), significantly lower (by $17.3 \%$ ) seed yield was obtained after having NT + WM compared to PT. Under somewhat more favourable conditions for oilseed rape growth in 2009 (yield 1.66$2.30 \mathrm{t} \mathrm{ha}^{-1}$ ) its yield was significantly higher (by $11.1 \%$ ) due to the application of PT + LS; however, the application of PT + GM and NT + WM demonstrated significantly lower yield (by $19.8 \%$ and $12.1 \%$, respectively) compared to PT. In 2010, the year favourable for oilseed rape emergence, the soil tillage methods had no significant influence on the yield $\left(1.82-2.01 \mathrm{t} \mathrm{ha}^{-1}\right)$. Application of NT + WM resulted in poorer oilseed rape seedbed preparation, and consequently poorer crop emergence. The negative influence of the mentioned conditions on the spring oilseed rape yield showed up during the year of a droughty post-sowing period. Use of PT $+\mathrm{GM}$ at the end of October 2008 with the purpose of achieving a higher amount of biomass of the cover crop, i.e. later than in other experimental plots, was carried out in wet soil. That could have influenced the decrease of spring oilseed rape yield in 2009.

Table 7. Seed yield of spring oilseed rape

\begin{tabular}{|c|c|c|c|}
\hline \multirow{3}{*}{$\begin{array}{l}\text { Tillage and its } \\
\text { combinations }\end{array}$} & \multicolumn{3}{|c|}{ Year } \\
\hline & 2008 & 2009 & 2010 \\
\hline & \multicolumn{3}{|c|}{$\mathrm{t} \mathrm{ha}^{-1}$} \\
\hline Deep ploughing (DP) & 1.61 & 2.08 & 2.01 \\
\hline Shallow ploughing (SP) & 1.68 & 2.12 & 1.96 \\
\hline Ploughless tillage (PT) & 1.68 & 2.07 & 1.98 \\
\hline $\begin{array}{l}\text { Ploughless tillage with } \\
\text { lime sludge (PT + LS) }\end{array}$ & 1.82 & $2.30^{*}$ & 2.00 \\
\hline $\begin{array}{l}\text { Ploughless tillage with } \\
\text { green manure }(\mathrm{PT}+\mathrm{GM})\end{array}$ & 1.80 & $1.66^{*}$ & 1.85 \\
\hline $\begin{array}{l}\text { No tillage in autumn with } \\
\text { winter mulch }(\mathrm{NT}+\mathrm{WM})\end{array}$ & $1.39^{*}$ & $1.82 *$ & 1.82 \\
\hline $\mathrm{LSD}_{05}$ & 0.168 & 0.224 & 0.183 \\
\hline
\end{tabular}

Interaction of treatment and year $F$-act. $-2.06^{*}$

A medium strong direct linear correlation was established between spring oilseed rape yield and structure index of seedbed in $2008(r=0.67, \mathrm{y}=0.92$ $+2.18 \mathrm{x}, P<0.01$ ), as well as a strong linear correlation was determined between the oilseed rape yield and crop germination rate (index of germination intensity) in 2009 $(r=0.74, \mathrm{y}=1.47+0.18 \mathrm{x}, P<0.01)$.

Experiments carried out on the loam soil of Central Lithuania established that the application of reduced tillage and direct drilling resulted in an increase in spring oilseed rape yield by $17.6 \%$ and $12.7 \%$, respectively in a dry year compared to conventional ploughing (Šimanskaitè et al., 2009). Jodaugiene et al. (2004) indicate that the research of the influence of shallow ploughing and ploughless tillage in long-term experiments demonstrated similar yields of oilseed rape as with conventional ploughing.

In France, Sauzet et al. (2003) established about $10 \%$ oilseed rape yield decrease due to the remaining pre-crop straw mulch and worse soil structure at $5-15 \mathrm{~cm}$ depth while applying reduced tillage and direct drilling compared to ploughing. In Finland, Peltonen-Sainio et al. (2011) concluded that the oilseed rape yield decrease is partially related to worsened penetration of its roots into deeper layers of soil, when direct drilling or reduced shallow tillage is applied. Trukmann et al. (2008) maintain that on Estonian compacted sandy loam soils 
spring oilseed rape can be cultivated more successfully and intensive tillage is less required for it compared to spring barley.

When applying ploughless tillage on Europe's scale, the crop yield is determined by many interacting factors and crop yields obtained are mostly somewhat lower compared to conventional ploughing (Van den Putte et al., 2010). The experiments performed in Sweden demonstrate that the application of ploughless tillage decreased the crop yield by only $1-2 \%$ compared to ploughing. The authors propose that it is not necessary to increase the depth of ploughless tillage in Swedish soils and it is possible to operate with shallow depths, especially in heavier soils (Arvidsson et al., 2013). Anken et al. (2004) propose that under wet and cold conditions of Switzerland's climate soil tillage intensity can be reduced without substantial yield decrease and soil quality will be improved. Stenberg et al. (2000) have reported that combination of shallow tillage with incorporation of lime materials led to increased yield of crops. Research carried out in the United Kingdom evidenced that the crop yield was somewhat lower due to ploughless tillage compared to ploughing and on clayey soils the crop yield decreased by actual $25-40 \%$ due to direct drilling compared to ploughless tillage or ploughing (Morris et al., 2010). Soane et al. (2012) indicate that with reference to the research performed in many European countries the application of direct drilling without prior soil tillage demonstrates about a 5\% crop yield decrease on average compared to ploughing. In Northern Europe a no-till system is more suitable for winter crops compared to spring crops. Therefore, the cultivation of spring oilseed rape on clay loam soils under the contrasting weather conditions requires careful choice of tillage methods and the use of additional agronomic practices to improve the emergence of crop and prevent yield losses.

\section{Conclusions}

1. Application of cover crop for winter mulch without autumn tillage and incorporation of lime sludge by ploughless tillage significantly increased the soil water content at the $5-15 \mathrm{~cm}$ depth directly after spring oilseed rape sowing compared to ploughless tillage alone. Application of shallow ploughing and ploughless tillage resulted in significantly lower soil water content in seedbed layer after oilseed rape emergence in droughty years compared to deep ploughing. Incorporation of lime sludge by ploughless tillage significantly increased soil water content in seedbed layer after crop emergence, while application of cover crop for winter mulch without autumn tillage and ploughless tillage with cover crop incorporation for green manure decreased soil water content in droughty years compared to ploughless tillage.

2. Application of cover crop for winter mulch without autumn tillage increased the proportion of cloddy $(>5 \mathrm{~mm})$ fraction, decreased the amount of most appropriate aggregates of $2-5 \mathrm{~mm}$ size and structure index, as the integrated indicator in the seedbed. Incorporation of lime sludge by ploughless tillage mainly helped to avoid the degradation of seedbed structure under ploughless tillage conditions, or even improved it.

3 . In all test conditions, especially in years with droughty post-sowing period, the germination rate of spring oilseed rape was the best after the incorporation of lime sludge by ploughless tillage had been applied. The weakest oilseed rape germination rate was registered due to shallow ploughing, ploughless tillage with cover crop incorporation for green manure and application of cover crop for winter mulch without autumn tillage. In droughty years, spring oilseed rape germination rate was influenced by the soil water content in the seedbed layer directly after crop sowing $(r=0.56, P<0.01)$, proportion of $2-5 \mathrm{~mm}$ soil aggregate fraction in seedbed structure $(r=0.50, P<0.05)$ and by the seedbed structure index $(r=0.50, P<0.05)$.

4. Incorporation of lime sludge by ploughless tillage significantly increased the spring oilseed rape yield by $11.1 \%$ in droughty year as compared to ploughless tillage. Application of cover crop for winter mulch without autumn tillage resulted in significantly lower oilseed rape yield by $12.1-17.3 \%$, ploughless tillage with cover crop incorporation for green manure by $19.8 \%$ under droughty conditions as compared to ploughless tillage. Spring oilseed rape yield in droughty years was influenced by the seedbed structure index $(r=0.67, P<0.01)$ and by the crop germination rate $(r=0.74, P<0.01)$.

\section{Acknowledgements}

The paper presents research findings, obtained through the long-term research programme "Productivity and Sustainability of Agricultural and Forest Soils" implemented by Lithuanian Research Centre for Agriculture and Forestry.

Received 06022014

Accepted 16092014

\section{References}

Anken T., Weisskopf P., Zihlmann U., Forrer H., Jansa J., Perhacova K. 2004. Long-term tillage system effects under moist cool conditions in Switzerland. Soil and Tillage Research. 78 (2): 171-182 http://dx.doi.org/10.1016/j.still.2004.02.005

Arvidsson J., Bölenius E. 2006. Effects of soil water content during primary tillage - laser measurements of soil surface changes. Soil and Tillage Research. 90 (1-2): 222-229 http://dx.doi.org/10.1016/j.still.2005.09.005

Arvidsson J., Westlin A., Sörensson F. 2013. Working depth in non-inversion tillage - effects on soil physical properties and crop yield in Swedish field experiments. Soil and Tillage Research, 126: 259-266 http://dx.doi.org/10.1016/j.still.2012.08.010

Atkinson B. S., Sparkes D. L., Mooney S. J. 2007. Using selected soil physical properties of seedbeds to predict crop establishment. Soil and Tillage Research. 97 (2): 218-228 http://dx.doi.org/10.1016/j.still.2007.09.017

Cherr C. M., Scholberg J. M. S., McSorley R. 2006. Green manure approaches to crop production: a synthesis. Agronomy Journal. 98: 302-319 http://dx.doi.org/10.2134/agronj2005.0035

Gruber S., Möhring J., Claupein W. 2011. On the way towards conservation tillage-soil moisture and mineral nitrogen in a long-term field experiment in Germany. Soil and Tillage Research. 115-116: 80-87 http://dx.doi.org/10.1016/j.still.2011.07.001

Feiza V., Feiziene D., Kadziene G., Lazauskas S., Deveikyte I., Slepetiene A., Seibutis V. 2011. Soil state in the $11^{\text {th }}$ year of three tillage systems application on a cambisol. Journal of Food, Agriculture and Environment, 9 (3-4): 311-328

Håkansson I., Myrbeck Å., Etana A. 2002. A review of research on seedbed preparation for small grains in Sweden. Soil and Tillage Research. 64 (1-2): 23-40 http://dx.doi.org/10.1016/S0167-1987(01)00255-0

Håkansson I., Arvidsson J., Rydberg T. 2011. Effects of seedbed properties on crop emergence. 2. Effects of aggregate size, sowing depth and initial water content under dry weather 
conditions. Acta Agriculturae Scandinavica, Section B: Soil and Plant Science. 61 (5): 469-479

http://dx.doi.org/10.1080/09064710.2010.506447

Jodaugiene D., Raudonius S., Spokiene N., Treciokas K., Stancevicius A. 2004. The influence of reduced soil tillage on soil properties and spring rape crop. Vagos, 62 (15): 12-18

Morris N. L., Miller P. C. H., Orson J. H., Froud-Williams R. J. 2010. The adoption of non-inversion tillage systems in the United Kingdom and the agronomic impact on soil, crops and the environment - a review. Soil and Tillage Research, $108(1-2): 1-15$ http://dx.doi.org/10.1016/j.still.2010.03.004

Peltonen-Sainio P., Jauhiainen L., Latinen P., Salopelto J., Saastamoinen M., Hannukkala A. 2011. Identifying difficulties in rapeseed root penetration in farmers' fields in northern European conditions. Soil Use and Management, 27 (2): 229-237 http://dx.doi.org/10.1111/j.1475-2743.2011.00331.x

Riley H., Børresen T., Lindemark P. O. 2009. Recent yield results and trends over time with conservation tillage on clay loam and silt loam soils in southeast Norway. Acta Agriculturae Scandinavica. Section B: Plant Soil Science. 59 (4): 362-372 http://dx.doi.org/10.1080/09064710802263200

Romaneckas K., Romaneckienė R., Sarauskis E., Pilipavičius V., Sakalauskas A. 2009. The effect of conservation primary and zero tillage on soil bulk density, water content, sugar beet growth and weed infestation. Agronomy Research, 7 (1): 73-86

Sauzet G., Reau R., Palleau J. 2003. Evaluation of oilseed rape crop managements with minimum tillage. Proceedings of the $11^{\text {th }}$ International Rapeseed Congress. Copenhagen, Denmark, 3: 863-864
Soane B. D., Ball B. C., Arvidsson J., Basch G., Moreno F., Roger-Estrade J. 2012. No-till in northern, western and south-western Europe: a review of problems and opportunities for crop production and the environment. Soil and Tillage Research. 118: 66-87 http://dx.doi.org/10.1016/j.still.2011.10.015

Stenberg M., Stenberg B., Rydberg T. 2000. Effects of reduced tillage and liming on microbial activity and soil properties in a weakly-structured soil. Applied Soil Ecology, 14 (2): $135-145$

http://dx.doi.org/10.1016/S0929-1393(00)00043-3

Šimanskaitė D., Feiza V., Lazauskas S., Feizienė D., Kadžienė G. 2009. Soil tillage systems impact on hydrophysical properties of Gleyic Cambisol. Zemdirbyste-Agriculture, 96 (1): 23-39 (in Lithuanian)

Tausojamoji žemdirbystė našiuose dirvožemiuose. 2008 [Sustainable agriculture on productive soils] / compiled by Maikštėnienè S. Lithuanian Institute of Agriculture, $344 \mathrm{p}$. (in Lithuanian)

Trukmann K., Reitam E., Kuht J., Nugis E., Edesi L. 2008. Effect of soil compaction on growth of narrow-leafed lupine, oilseed rape and spring barley on sandy loam soil. Agronomy Research, 6 (1): 101-108

Van den Putte A., Govers G., Diels J., Gillijns K., Demuzere M. 2010. Assessing the effect of soil tillage on crop growth: a meta-regression analysis on European crop yields under conservation agriculture. European Journal of Agronomy, 33 (3): 231-241

http://dx.doi.org/10.1016/j.eja.2010.05.008

Теории и методы физики почвы. 2007 [Theories and methods of soil physics] / compiled by Shein E. B., Karpachevskij L. O. Тула, 616 p. (in Russian)

ISSN 1392-3196 / e-ISSN 2335-8947

Zemdirbyste-Agriculture, vol. 101, No. 4 (2014), p. 347-354

DOI $10.13080 / \mathrm{z}-\mathrm{a} .2014 .101 .044$

\title{
Žemès dirbimo, kalkių purvo ir tarpinio pasėlio ịtaka dirvožemio fizinei būklei ir vasarinių rapsų augimui
}

\author{
A. Velykis, A. Satkus, L. Masilionytė \\ Lietuvos agrarinių ir miškų mokslų centro Joniškèlio bandymų stotis
}

\section{Santrauka}

Tyrimai atlikti 2008-2010 m. Lietuvos agrarinių ir miškų mokslų centro Joniškèlio bandymų stotyje giliau karbonatiniame giliau glejjiškame sunkaus priemolio rudžemyje (RDg4-k2). Tyrimų tikslas - ịvertinti gilaus (20$23 \mathrm{~cm})$ ir seklaus $(15-17 \mathrm{~cm})$ arimo, bearimio dirbimo $(10-12 \mathrm{~cm})$, bearimio dirbimo $(10-12 \mathrm{~cm})$ derinių su kalkių purvo ir tarpinio pasèlio (pašarinių žirnių, vasarinių vikių bei siauralapių lubinų mišinio) žaliajai trąšai itterpimu ir to paties tarpinio pasèlio panaudojimu mulčiui be žemès dirbimo rudenị ịtaką dirvožemio fizikinèms savybėms ir vasarinio rapso (Brasica napus L.) augimui. Po seklaus arimo vasarinių rapsų sèklų guoliavietėje (0$5 \mathrm{~cm}$ gylyje) tuoj po jų sèjos sausringais metais (su posejjinio periodo trukme be lietaus 18 ir 20 dienų atitinkamai 2008 ir 2009 m.) drégmès kiekis buvo iš esmès mažesnis, o rapsų dygimas prastesnis nei giliai ariant. Dèl bearimio dirbimo sèklu guoliavietèje sausringais metais drègmès kiekis buvo iš esmès mažesnis, o jos struktūra prastesnẻ normalaus drègnumo metais nei giliai ariant. Kalkių purvo ịterpimas kartu su bearimiu dirbimu lèmé geresnę sėklų guoliavietès struktūrą, didesnị drègmès kieki $5-15 \mathrm{~cm}$ gylyje ir didesni rapsų dygimo intensyvumą, palyginus su vien tik bearimiu dirbimu. Sausringais metais kalkių purvo įterpimas rapsų sèklų derlių taip pat padidino 11,1\%. Vèlu rudeni bearimiu dirbimu iterpus tarpinio pasèlio mase žaliajai trą̌ăai, rapsai sausringais metais iš esmès prasčiau dygo, jiems sudygus sèklų guoliavietėje liko mažiau drègmès ir derlius, palyginus su bearimiu dirbimu, sumažèjo 19,8\%. Tarpinị pasèli mulčiui rudeni palikus žiemai be žemės dirbimo, iš esmès daugiau drègmės buvo 5-15 cm gylyje po rapsų sèjos, tačiau sausringais metais prastėjo sèklų guoliavietès struktūra, joje mažèjo drègmès kiekis, rapsai prasčiau dygo, jų derlius sumažèjo 12,1-17,3\%, palyginus su bearimiu dirbimu. Sausringais metais vasarinių rapsų dygimo intensyvumas priklausė nuo drégmės kiekio sėklų guoliavietèje tuoj po sẻjos $(r=0,56$, $P<0,01), 2-5 \mathrm{~mm}$ dydžio dirvožemio dalelių kiekio joje $(r=0,50, P<0,05)$ ir jos struktūringumo $(r=0,50$, $P<0,05)$, išreikšto koeficientu, o sẻklų derlius - nuo sėklų guoliavietės struktūringumo $(r=0,67, P<0,01)$ ir rapsų dygimo intensyvumo $(r=0,74, P<0,01)$.

Reikšminiai žodžiai: augalų dygimas, bearimis dirbimas, derlius, dirvožemio drėgmės kiekis, mulčias, vasariniai rapsai, žalioji trąša. 